Article

\title{
(De)Centralization of the Global Informational Ecosystem
}

\author{
Johanna Möller * and M. Bjørn von Rimscha \\ Department of Communication, Johannes Gutenberg-University Mainz, 55128 Mainz, Germany; \\ E-Mails: johanna.moeller@uni-mainz.de (J.M.), b.vonrimscha@uni-mainz.de (M.B.v.R.) \\ * Corresponding author
}

Submitted: 17 June 2017 | Accepted: 25 August 2017 | Published: 22 September 2017

\begin{abstract}
Centralization and decentralization are key concepts in debates that focus on the (anti)democratic character of digital societies. Centralization is understood as the control over communication and data flows, and decentralization as giving it (back) to users. Communication and media research focuses on centralization put forward by dominant digital media platforms, such as Facebook and Google, and governments. Decentralization is investigated regarding its potential in civil society, i.e., hacktivism, (encryption) technologies, and grass-root technology movements. As content-based media companies increasingly engage with technology, they move into the focus of critical media studies. Moreover, as formerly nationally oriented companies now compete with global media platforms, they share several interests with civil society decentralization agents. Based on 26 qualitative interviews with leading media managers, we investigate (de)centralization strategies applied by content-oriented media companies. Theoretically, this perspective on media companies as agents of (de)centralization expands (de)centralization research beyond traditional democratic stakeholders by considering economic actors within the "global informational ecosystem" (Birkinbine, Gómez, \& Wasko, 2017). We provide a three-dimensional framework to empirically investigate (de)centralization. From critical media studies, we borrow the (de)centralization of data and infrastructures, from media business research, the (de)centralization of content distribution.
\end{abstract}

\section{Keywords}

business models; centralization; content-oriented media companies; decentralization; digital media platforms; distribution; Facebook; Google; technology infrastructures

Issue

This article is part of the issue "Acting on Media: Influencing, Shaping and (Re)Configuring the Fabric of Everyday Life", edited by Sigrid Kannengießer and Sebastian Kubitschko (University of Bremen, Germany).

(C) 2017 by the authors; licensee Cogitatio (Lisbon, Portugal). This article is licensed under a Creative Commons Attribution 4.0 International License (CC BY).

\section{Introduction}

The digital era is having painful consequences for media companies such as publishers or broadcasters whose core business is providing content. "It hurts", says one of the contributors to the study presented in this paper [3]. The interviewee, CEO of an Austrian newspaperpublishing house, refers to the radical, transformative process to which content-oriented media companies are exposed. Their traditional subscription- and advertisingbased business models, oriented toward national media systems, are expiring. An important reason is that media companies such as Facebook or Google, whose business models focus on technologies and technology infrastructure and whose platforms cut across national regulations, are winning market shares, especially in advertising. Media business and journalism studies have identified the various stages in trial-and-error attempts by content-based media companies to adapt or reinvent content monetization in a digital age. The initial idea to provide free content on websites and sell advertising space has failed (Bakker, 2008). Paid content, a thenemerging model, was accepted by users only in exceptional cases (Herbert \& Thurman, 2007).

At the present time, we can identify three major strategies for dealing with the dominance of digital plat- 
forms in media markets. One is to regard content as the carrier of product promotion with, for instance, native advertising playing a major role (Matteo \& Dal Zotto, 2015). This strategy aims to solve, for instance, the problem of increased ad blocker usage. In a second strategy, research observes a qualitative shift toward using and designing infrastructures. Companies increasingly engage in building their own databases and technological interfaces, e.g. The Intercept (Mullin, 2015). Finally, media companies increasingly engage in national and transnational lobbyism in order to support political efforts to regain control of data and distribution (e.g. Arsenault \& Castells, 2008). Contemporary strategies, thus, clearly do reach beyond the level of content creation, as they refer equally to the design, shape, and development of (media) technologies and technology infrastructures.

Content-based media companies, therefore, qualify as a subject of research when regarding agents that act on media (Kubitschko, 2017). Acting on media denotes actively aiming at shaping technology (infrastructures) that is crucial for everyday communication by contributing to technology design or discourse. Thus far, critical media research as well as research in the area of media practice has placed a focus on agents that belong to the citizenry, such as civic hacking as lobbyism (Coleman, 2011; Kubitschko, 2015) or grass-root technology movements (Milan \& Hintz, 2013), or on "digital media giants" (Birkinbine et al., 2017), on the other hand. With its focus on content-based media companies, this article ventures into another thus far overlooked group of agents. That is, our investigation departs from the insight that these companies, challenged by considerable technological change as well as the increasing market power of influential digital platforms such as Facebook and Google, have every interest in engaging in shaping technology and technology infrastructures. Yet though, they dispose of considerable influence and eventually the potential and pressure to shape technology and infrastructures. Moreover, as their economic survival might depend on it, it is worth to consider their efforts to act on media.

Our argumentative starting point is that contentbased media companies are in a competitive struggle with large digital platforms and that it is worth investigating their business strategies in relation to technology and technology infrastructures. A helpful distinction for grasping this relationship is that of centralization and decentralization, both used in critical media research. Centralization refers to the concentration of control over technology and technology infrastructures in the hands of dominant media platforms or governments (Dencik, Hintz, \& Carey, 2017; Helmond, 2015; Mathew, 2016), while decentralization denotes giving control of data (back) to citizens. In the following, we will explore this analytical perspective and aim to describe contentbased media companies as agents of decentralization or centralization. To this end, we combine perspectives from critical media studies with insights from media business and management. Both contribute to the devel- opment of a three-dimensional framework for assessing (de)centralization patterns in media-company business strategies, which is applied to data from a research project on the cross-border activities of media companies. In particular, we refer to qualitative interviews with 26 leading managers from Europe- and US-based media companies whose core business is content in contrast to technology.

\section{2. (De)Centralization: A Techno-Economic Framework}

In communication and media studies, the issue of decentralization has gained increasing importance against the backdrop of contemporary "surveillance societies" (Lyon, 2011), a term coined by sociologist David Lyon for societies characterized as monitoring any kind of everyday communicative activity. The concept is a key anchor for a body of communication and media research that critically discusses control over data and data flows in digital societies (Hintz, 2014). Herein, control over data is a key resource for political and economic power. While centralization refers to the control over data by governments or digital media platforms like Google or Facebook, decentralization denotes giving that control to users, or rather citizens. Thus, centralization by commercialized digital platforms, in cooperation with governments, is described as the status quo, whereas decentralization refers to civic stakeholders' attempts to acquire control over data.

Both concepts scrutinize the commodification of everyday communication. Researchers critically assess individual user control of data (e.g., via encryption) in contrast to more democratic and citizen-based models of data sharing (Fuchs, 2017, p. 437; Gürses, 2014). Following Agre, centrality is given when digital infrastructures are "administered by a centralized authority...and if...global coordination is required to change them" (Agre, 2003 , p. 40). Digital media platforms are unanimously criticized for their practice of centralizing communication and data flows and their lack of respect regarding privacy (Helmond, 2015; Hintz, 2014, p. 360; Kubitschko, 2015, p. 78; Milan, 2015 , p. 3) while, at the same time, creating a discourse of decentralized empowering of platform technologies (Gillespie, 2010). Facebook, for instance, is described as "the most subtle, cheapest, and best surveillance technology available" (Nadir, 2012). From a political economy perspective, yet pointing to a similar argument, Christian Fuchs (2017) critically analyses Facebook's practices of turning user access into a commodity by centralizing data analysis. Rieder and Sire (2014, p. 208) stress how Google has overcome "the limits which physical space imposes on the centralization of information services".

Decentralization, in contrast, is tied to the idea of a more democratic Internet. This is the case when its applications "arise in a locality and propagate throughout the population" (Agre, 2003, p. 40). Decentralization is defined as giving control of data and technology to citi- 
zens. In the literature we find only minor disagreement on its value, if at all it concerns the necessary degree of decentralization. While some regard decentrality as a key feature of the early Internet representing an ideal digital-infrastructure design (Hintz, 2014, p. 352), others contend that the decentralized Internet is a "myth" (Mathew, 2016). Based on a review of the history of the Internet, Mathew elucidates that it was and always will be hierarchically organized. His argument is that a certain degree of centralization is necessary to ensure political control over digital infrastructures. Agre's earlier considerations sound similar. He highlights that the Internet has "a reputation as a model of decentralization", although "its institutions and architecture nonetheless have many centralized aspects" (Agre, 2003, p. 40).

Three groups of stakeholders are studied as agents of decentralization. The first group comprises civil society lobbyists who inform the public, as well as governments, regarding the dominant role of digital media players by means of hacking and informing (Coleman, 2011). A prominent example is the Chaos Computer Club (Kubitschko, 2015). A second group comprises encryptiontechnology activists, implying the structural analysis of encryption technology. Here, the focus is on providing secure, i.e., anonymous, spaces of communication to technology users (Gürses, 2014). A third group can be characterized as system-opposing civil society actors, creating alternative digital infrastructures and "adopting a tactical repertoire of circumvention" (Hintz, 2014, p. 353), who bypass generally applied systems by developing alternative communication platforms that are not linked to the dominant digital infrastructure (Milan \& Hintz, 2013). This, by and large, demonstrates that (de)centralization in critical media studies is either focusing on increasing control of data flows by (commodified) surveillance organizations or by empowered, technology-savvy citizens. While the former exert control over massive sets of data, the latter represent an elite with limited influence on a large scale.

As these agents engage in shaping and debating technologies and technology infrastructures, they act on media. We argue that it is worth investigating content-based media companies by applying the same perspective. Acting on media "entails the direct engagement with technical systems and devices as well as the articulation of viewpoints, interests, experiences and viewpoints" (Kubitschko, 2017, p. 5) that are related. In contrast, acting with media denotes the use or impact of media. Content-based media companies are defined as companies whose business model is based on the production and trade of text or audio-visual content. We have in mind newspaper, book, and special-interest outlet publishers as well as TV and movie content producers and traders. Within these companies, technology plays a subordinate yet growing role in supporting the provision of content and increasing added value. In contrast, technology-based companies regard platforms, data collection and analysis, and the development of technolog- ical solutions as their core business. Content is predominantly provided by users, which might as well be contentbased media companies.

The distinction between content- and technologybased media companies provides a useful analytical map for characterizing media companies' business strategies whose core business is content and who engage increasingly with technologies and technological infrastructures. Following critical media research, we regard Facebook and Google as technology-based companies that clearly centralize media markets (Helmond, 2015; Mathew, 2016). That is not to say that technology-based companies generally centralize the global informational ecosystem. Yet Facebook and Google represent key reference platforms for the identification of centralization among content-based media companies. While, for a long time, media companies seemed to merely lag behind digital development, bemoaning the increasing market power of digital platforms, they are now continually developing new business models. With reference to centralization, we want to know whether these adapt to or copy Facebook's and Google's business models and thus tend to support their influential market position. The following quote illustrates that there is an inevitable and subordinate dependence on digital platforms:

News organizations are increasingly dependent on Google and a handful of other powerful tech firms for the tools and platforms needed to reach their audience. They also are increasingly vulnerable to the changes the tech firms are introducing. The shift to mobile, for example, is making news an ever-more expensive arena in which to operate, but it is not yet producing the kind of new revenues to back up news organizations that will allow them to support those expenses. (Sasseen, Olmstead, \& Mitchell, 2013)

Despite these tendencies to centralize, business relations between content-based media companies and digital platforms are more complex. By the same token, the above quote could be read in the sense that contentbased media companies are likely to be agents of decentralization. Media business researchers point out that digital media platforms dominate and control the advertising market by increasing user access and scope. While digitization forces them to provide their content online, they struggle for new ways to monetize it. Earlier business models based on subscription and advertising that flanks coverage or subscription, are increasingly called into question, not least by these digital platforms. From a decentralization perspective, one could argue that content-based media companies share a critical perspective on digital media platforms. Their joint intent must be to limit Facebook's, Google's, and other platforms' rigorous access to users and data in order to regain control of their core businesses.

Taking into account that content-based media companies most likely perform as both centralization 
and decentralization agents, we suggest considering (de)centralization with regard to three dimensions; that is, the normative implications of both notions are pushed to the background. A first dimension concerns control over data and data gathering. Critical media studies demonstrate that understanding who controls data flows is paramount for investigating centralization and decentralization in critical digital society and technology studies (see also Fuchs, 2017). As content-based media companies will hardly intend to give control of data to users, we must rather imply that the question arises of who can exert control over user access and data in order to commodify them. This perspective regards both technologyand content-based media companies as competitors within a global informational ecosphere (Birkinbine et al., 2017), with the former in a central position and the latter, to a greater or lesser extent, located at the periphery. It also pays tribute to the fact that digital media platforms can increasingly be regarded as "content workers", as they exert a gatekeeper function by filtering content published on their platform. Recently, we have seen many examples showing that Facebook and Google edit and filter content provided on their platforms (Hintz, 2014).

Critical media researchers might argue that capitalist agents will not contribute to sustainable democratic solutions to surveillance (Fuchs, 2017, p. 442). Equally, scholars investigating media diversity contend that highly competitive deregulated media markets will not result in a diversified media market (Jakubowicz, 2013). For instance, Just (2009, p. 111) holds that this might lead to an increase of niche market products but not cover all societal groups that would be considered in a politically regulated context. We do share these critical concerns but not their radical implications. Mathew argues that the idea of a decentralized Internet is a myth, as even at the beginning there were centralized structures to control communication flow (Mathew, 2016). Similarly, current models of Internet governance design multi-stakeholder processes, including both civil and economic actors (Hofmann, Katzenbach, \& Gollatz, 2014), "a complex ecology of interdependent structures" with "a vast array of formal and informal mechanisms working across a multiplicity of sites" (Hintz, 2014, p. 351). Within these centralized and decentralized structures, Facebook and Google indeed play a "central" role. As media environments are constantly deregulated and digital media platforms by and large circumvent political regulation, we thus investigate the potential of media companies to counterbalance centralized digital media platforms' data collection regarding regional or local data centres by as many different agents as possible.

Building on this perspective, we introduce additional dimensions of (de)centralization. With reference to the research of McKelvey (2011) or, more recently, Helmond (2015), which deepens our perspective on data collection, we introduce a second dimension of (de)centralization. These authors place a focus on data accumulation by global digital-technology companies while also considering their business models regarding technological infrastructures as a moment of centralization. Helmond, in particular, has underlined the close relationship between building "decentralizing platform features" and "recentralizing platform-ready data" (Helmond, 2015, p. 8). That is, business models are related to technological infrastructures. Digital media companies build platforms that decentralize in the web in order to realize accessibility for as many users as possible. Following Gillespie (2010, p. 352), using the platform notion allows digital media platforms to create a discourse of equal access while exercising extensive economies of scale. Platform is defined as "a 'raised level surface' designed to facilitate some activity that will subsequently take place" (Gillespie, 2010, p. 350).

The technological infrastructure is the companies' key resource. This infrastructure is "programmable", which describes the potential for customization by external developers and its reuse by various business models and applications (Andreessen, 2007). The platform's key technologies are application-programming interfaces (APIs), which are structures on which to build software applications. At the same time, they allow for the exchange of content and data created across these applications. The platform, on the one hand, provides applications for users that can look very different and can vary across economic and cultural contexts; yet on the other hand, its technological foundation is a single software infrastructure built with the aim of creating a large database.

Translated to a market perspective, Facebook, for instance, is "an example of a multi-sided platform that connects users, advertisers, and third-party developers and experiences network effects where value increases for all parties as more people use it" (Helmond, 2015, p. 2). Facebook is an outstanding example of this specific interplay of "decentralizing platform features and recentralizing platform-ready data" (Helmond, 2015, p. 8) for commodification. Facebook offers an interface that invites new software applications and integrates existing ones. Not least, it increases benefits for users (i.e. networking), the more they use it for everyday communication. This, altogether, allows us to consider (de)centralization with regard to its infrastructural foundation. Hence, we will ask whether content-based media companies build applications that align with digital-media platform interfaces, eventually to profit from the platform's visibility among users, or concentrate on building their own or alternative technological frameworks.

Finally, we refer to a third dimension of (de)centralization that is rooted in the media-business literature and centres on content distribution. Traditionally, media production has been much less concentrated than media distribution. Depending on the media technology in question, concentration on the distribution level is higher (fewer film distributors than film producers) or even reaches a natural monopoly, for instance, in the case of 
cable television or, in some countries, magazine distribution to news stalls (May, 2012). ${ }^{1}$ Disadvantages of this centralization are regularly addressed by imposing mustcarry rules or indiscriminate access to distribution (see Bernstein, 1986; Woldt, 2002). Furthermore, concentration or centralization in one media-distribution technology can be counterbalanced with and within other media technologies.

The digitization of media distribution changes the situation. The Internet is content- and format-agnostic and thus can more or less replace and incorporate all other media distribution technologies. Therefore, a digital platform that centralizes content and communication is much more all encompassing on an overall scale than centralized platforms in other media distribution technologies have been. In some sense, the discussion about net neutrality (Economides, 2008) mirrors access regulation in traditional media-distribution technologies. However, centralization does not happen only on the level of the broadband connection but also on the level of digitalmedia platforms such as Facebook or Google. Thus, even a non-discriminatory network does not hamper centralization. Strong network effects on such platforms create winner-take-all markets (Noe \& Parker, 2005), but they do not justify a natural monopoly. Media companies as producers would still benefit from a multitude of distribution options.

For legacy media organizations, these universal digital-distribution platforms are a boon and a bane at the same time. Using the APIs offered by the platforms, they can reach large audiences without creating their own infrastructure. However, their grip on this enlarged reach is rather limited. The platforms will not share all the information they have on users, while they will secure a large part of the potential advertising revenue. With Facebook's instant articles or Google's accelerated mobile pages, the two companies offer to host content and allow for superior digital distribution. This renders media companies dependent and creates new barriers to market entry. Economies of scale in the analogue world meant that the price of a printing press posed a marketentry barrier in the newspaper business (Picard, 2015). Economies of scale in the digital world mean centralization on digital media distribution platforms poses barriers to entry into the digital media market.

Having said this, we understand that an ongoing centralization of the global informational ecosphere occurs if the content-based media companies arrange their business models with a view toward the dominant digitalmedia platforms. Decentralization, in contrast, refers to alternative or owned databases, infrastructures, and distribution channels. Regarding these three dimensions, we will investigate business strategies as pursued by content-oriented media companies with regard to the three dimensions described earlier (data, platforms, and distribution). Overall, the contribution of this approach is to investigate whether content-oriented media com- panies must be regarded as agents of centralization or decentralization of the global informational ecosphere.

\section{Research Questions and Methods}

The above-introduced framework suggests a way to approach media companies as agents of (de)centralization. Each of the three dimensions in the framework addresses a specific research question. With respect to data, we ask whether and to what extent media companies adapt to platform types of data collection to design their products. Then, we are interested in adaption to digital platform interfaces or, in contrast, the creation of alternative or independent infrastructures. Finally, we want to find out more about the uses of distribution channels. Herein, decentralization refers to independence from centralization for arranging business models with a view toward Facebook, Google, and the like.

These research questions will be explored based on a study of the cross-border activities of media companies (additional information about the research project can be found in the acknowledgements). The issue of centralization or decentralization is, thus, not addressed directly. This is related to limitation and surplus at the same time. Many questions that could have been asked to further elucidate a company's relationships with technology (infrastructures) remained unasked. Thus, while the empirical study presented in this article is an academic side product, it points out that questions regarding the relationship with digital platforms and technology infrastructures are highly relevant to top-tier media managers, as they emerge without being asked directly.

We used qualitative semi-structured interviews (Cooper \& Schindler, 2014; Patton, 2015) with 26 leading media managers, responsible mostly for their respective company's engagement across borders, from contentbased media companies based in Austria, Belgium, Germany, the UK, the US, the Netherlands, and Switzerland to address these (project-related) questions (for a list of all interviewees, please see the Annex). The interviews were conducted predominantly in face-to-face situations, seven via Skype, and one by telephone. The sampled companies represent a large variety in terms of content (newspaper publishing, news agencies, book publishing, TV/movie). Despite this diversity, all of the interviewees reflected on their companies' relationships with global digital platforms. We did not aim to cover the companies in terms of trade volume but rather aimed for a variety of cross-border activities.

\section{Content-Based Media Companies as Agents of (De)Centralization}

Above, we have demonstrated that the rise of Facebook, Google, and the like poses a considerable challenge for content-based media companies, as the former dominate advertising markets, push technological inno-

\footnotetext{
${ }^{1}$ For a critic on the theory of natural monopolies in media distribution, see DiLorenzo (1996).
} 
vation, and control data and, to some extent, distribution. The interviews underline how technology companies have shaped the media market considerably since the 2000s. In a typical statement, Piet Vroman, CFO of the Belgian newspaper company DePersgroep, highlights how Google and Facebook have pushed the economies of scale: "Google entered, and Facebook entered, and advertising revenues dropped heavily. And we learned more and more, which was not that important in the 1990 s, until by 2005 , that scale became ever more important" [23]. Other interviewees put it similarly. In the words of Axel Springer International's then-president Ralph Büchi, "in this new digital allocations battle with the big...platforms...we will have no chance if there is no prevention against their market power being used to our clear disadvantage" [5]. These two quotes illustrate that leading content-based company managers see the clear need to act. They express concerns regarding nothing less than their economic survival. In this difficult situation, the interviewees consider their engagement with technology (infrastructures) as well as their relationships with centralized digital platforms. Approaches to data, formats, and distribution that will be discussed in greater detail in the following, must be understood against this background.

\subsection{Data}

Access to data is a key resource for content-based media companies in order to able to control the alignment between products and consumers' needs. Yet control over data remains largely with the digital media platforms. In the interviews, we identify three general strategies to deal with this problem; none aims at sharing data with global media platforms, yet all three clearly follow comparable patterns. The first strategy refers to digital platforms as a role model. That is, media companies contend the need to adapt their business models to datacollection strategies applied by Facebook, Google, and the like. This is illustrated in the following quote by Time Warner's senior vice president:

We need to develop our data capabilities to better understand consumer needs....moving away from ratings, which is really an outdated model, in a data-centric world, so that we can...show advertisers not only that they're reaching eight million women in the ages of 18 to 34 , but also that you're reaching car buyers who went to the concessionary the following day. So we really have to evolve the model because that's what our competition is doing. [19]

Heading in the same direction, the chief financial officer of the Belgium newspaper-publishing house DePersgroep states that digital media companies are "miles ahead of us in terms of knowing your customer" [23]. DePersgroep initiated a project to generate valuable data access. Based on a cooperative venture with other
Belgium-based media companies, the newspaper publisher tried to establish a central media ID that would provide a single access to a broad media portfolio. The intent of this platform was clearly to collect user data, yet it failed, not because of the politician responsible but, as the CFO underlines, because of one of the media companies.

A second strategy is to create global databases in niche markets. Often, this strategy builds on alreadyexisting data or networks in traditional businesses. Managers considering this option explore issue-specific data that they retrieve from their particular areas of expertise. An illustrative example is Elsevier; the scientific publisher uses journal and expertise databases to provide analytical services to scientists (career and collaboration planning), universities (strengthening profile) or governments (funding). Mark Siebert, Director of Engagement Programs and Strategy, explicates that, very similar to the role-model strategies, Elsevier wishes to "learn from the people and their needs" [14], with a focus on cosmopolitan groups of scientists and universities. Then, learning from these customers means creating a platform that will play a key role in this field, at least for those who can afford it. A similar example is that of specialist magazine publisher Vogel. The media company uses contact networks and expertise from formerly printed advertisement-based newsletters to build issue-specific expert platforms and networks in very specific areas such as trading old-fashioned spare parts or specific machines for ceiling construction.

A third strategy for gaining control over data, finally, is to create local data-product communities. This strategy is applied by Tamedia, a Swiss publisher and commuter newspaper specialist. The Swiss paper 20 Minutes combines a strategy of community creation, data collection, and newspaper production. Content is published throughout the day and favorite topics will appear in the printed evening edition. Tamedia's "strongest digital competitors are Facebook and Google....It is not realistic to compete with them" [9], says Managing Director Marcel Kohler. Yet equally, Tamedia belongs to the category of "social media" [9], as it provides a brand to engage people within the 20 Minutes community, where readers communicate with the editors and with each other and provide content and pictures. And, as Marcel Kohler contends, "the vessel that keeps everything together is our app" [9]. Even though 20 Minutes is a successful brand in Luxembourg, Denmark, and other countries, it is a national concept, as the respective 20 Minute communities relate to national or local surroundings yet merge into one database via the media company Tamedia.

With the limited number of media-company representatives interviewed, these three strategies certainly represent only a small fraction of content-based media companies' strategies for retrieving control of data. Yet they illustrate that media companies have no access to data collected by Facebook and Google, nor do they explicitly contribute to digital platform data collection. 
Rather, content-based media companies seek avenues of independent data gathering. For citizens, this is not necessarily good news, as they can expect a multiplicity of databases where their individual data is stored. Similarly, taking a global, informational-ecosphere perspective, we can contend that these and similar business strategies would generate a multiplicity of data centers. This would, from the perspective of the interviewees, at best include some European data compactions.

\subsection{Infrastructure}

We have argued that technology-based media companies provide programmable platforms. That is, they provide an interface to which external developers can link. Alternatively, digital media companies can acquire external applications and add them to their interface. Helmond has demonstrated that this programmability refers to platforms with centralized data collection and decentralized applications. While data centralization has already been discussed, in this section, we want to offer an idea of whether or not content-based media companies link to digital media platforms and, if so, how. In particular, we are interested in whether, in their everyday workflows, media companies adapt to dominant platforms or aim to establish other technological structures. The following illustrates that both apply. Media companies profit from applying existing technological solutions but equally consider the advantages of remaining independent.

Numerous content-based media companies clearly favor the application of technology-provided dominant media platforms. ITV Studios Managing Director Ella Umansky, for instance, contends that secure data transfer is crucial for selling TV content across the world: "If you have problems with delivery, the file is the wrong format or gets corrupted whilst it's being transferred, that kills the deal, and that could then kill the relationship" with the customer [15]. ITV studio, the biggest commercial television network in the UK, depends on technological solutions provided by an internationally applicable system for secure and direct transmission of content. Based on this secure transmission, the company makes money. CEO and Austrian newspaper publisher Kralinger reports that his company works with Google editing technology, as it offers tailored solutions for editing-specific requirements: "Alphabet (Google's parent company) by now offers very, very much technology, and during the last 12 to 18 months also their will to work with publishers in a constructive way has considerably increased" [2]. Beyond secure and well-aligned technologies, digital media platforms offer solutions for reducing costs within everyday business. Book publisher Diogenes managing director, for instance, refers to the fact that using digital technology solutions provided by dominant platforms can bring about financial savings yet calls for additional financial investment in the beginning [4].
At the same time, the interviewees provide numerous examples of not linking to programmable large digital platforms and express aspirations to do so in the near future. Kralinger, the Austrian newspaper publisher, while using Google technology in its everyday editing business, contends the need for European media companies to cooperate in order to advance Europebased editing system technology networks. From his point of view, there is a clear increase in "consciousness that we need to build an independent market in Europe, which appeals against the big American companies" [2]. He reports supporting experiments with an open-source content-management system called Drupal. Similarly, news agency APA's CEO Clemens Pig puts forward that "technology is a protective shield against competitors" [3] and underlines the need to cooperate on a European scale.

Beyond that, we find two other compelling ways of not linking to dominant media platforms. One is to equally provide a platform that is a programmable interface. This is especially the case with companies that use their traditional content-based business to turn it into databases. Herein, the above-introduced example of Elsevier may be illustrative. Elsevier is part of the UK RELX group that, besides the scientific publisher, owns businesses such as financial services or an event agency. Elsevier is part of the RELX Group, a global provider of information and analytics for professionals and business customers across industries. Mark Siebert, leading Elsevier manager, explains that information and analytics help public administrations and scientists, among others, to build strategies or support career decisions [14]. In contrast, other larger media companies with a diverse product portfolio, such as Axel Springer or Thomson Reuters, tend to opt for a second opportunity. Interviewees from both companies contend that the investment in a coherent company-wide technological framework represents a high financial risk. Gonzalo Lissarrague, Thomson Reuter's president, Global Growth Organization, says that what is global is the professional network and the knowledge, but "we don't want to replicate or duplicate the technology in every country" [17].

Therefore, in regard to infrastructure, we find that content-based media companies' links with digital media platforms are highly diverse. While some companies measure the financial benefits of applying global platform technology, many others attempt to link to alternative infrastructures; that is, they do not follow a coherent technology development strategy. In this sense, we can hardly speak of content-driven media companies as agents of centralization. Only some express a "structural pressure" to adapt to centralized infrastructures. In contrast, we find numerous approaches for building their own platforms or comments on conscious decisions to not build a coherent technological infrastructure. Decentralization references are remarkably present on a discourse level. 


\subsection{Distribution}

Finally, we are interested in the strategies media companies intend to apply regarding distribution. Drawing on media business literature, we have argued that centralized distribution as provided by Facebook and Google are a boon and a bane at the same time. Content-based media companies face the dilemma of choosing between reaching large audiences and losing control over data (and, thereby, advertising revenue). It is, therefore, no surprise that the business relationships of content-based media companies with digital media platforms are complex from a distribution perspective. In fact, as the following quote by Bernhard Burgener, CEO of the Highlight Communications Group exemplifies, the interviewees clearly regard Facebook and Google as exerting control over distribution: "For them [Silicon Valley elites], it was always the platform, the distribution, and the client..... Once you have the customers and you have the distribution, you have the business. This is fundamental" [8].

The following illustrates that a majority of contentbased media companies have accepted Facebook, Google, and the like as key distributors of media content. However, not only do media companies depend on the digital platforms; the platforms also depend on the content provided by the media companies. Motor Presse representative Volker Breid, for example, a special-interest publisher with a focus on cars and mobility, underlines how crucial it is to be present via Facebook, stating, "this is important to maintain relevance" [13]. He further explains that preparing content for distribution on Facebook has become an integral part of the everyday production process. Also Swiss book publisher Diogenes, who has taken more time to digitalize its product portfolio, is now available throughout the platforms, "because this is what the authors want" [4]. Also another large German multimedia company's strategy, preferring to stay anonymous regarding this aspect, aims at an adaptation to digital platform distribution, stating that the company maintains a stable business relationship with Google, Amazon, Facebook and the likes.

In this context, however, it is important to stress that the content-based media companies are fully aware of the advantage of "having the content" [4]. While visibility and reaching a large audience is not always profitable for a newspaper business, book publishers and TV producers can be in a far more comfortable position, which is even more comfortable in the event that the respective media company disposes of alternative distribution channels and can negotiate with digital media platforms. Movie and TV content producer Story House, for example, has just recently initiated a promising collaboration with YouTube. Still, there are many other ways to produce and sell content. The same holds true in the case of Bertelsmann. Amazon is an interesting partner from an economic point of view, but it is not the only option.

Overall, our take on distribution reveals, once again, a mixed picture. Many content-based media companies reconsider their business models by trying to benefit from collaboration with digital media platforms. The revenue appears more attractive when there are alternative distribution channels. At the same time, media companies are aware that digital media platforms cannot live on user-generated content alone, but that they must depend on professionally produced content as well. This insight increasingly strengthens the media companies' market power, yet always based on a relationship with digital media platforms.

\section{Conclusion}

This study contends that content-based media companies act on media. They engage with and define business strategies regarding technology (infrastructures). However, content-based media companies can neither be regarded as agents of decentralization nor centralization, especially when applying a critical and citizen-oriented perspective. The above insights have shown that contentbased media companies contribute to and push centralization processes pursued by Facebook, Google, and the like. The above illustrates that, at first sight, contentbased media companies tend not to directly contribute to the platforms' data collection. Simultaneously the centrality of digital technology and the analysis of big data for the development of further media content-related business is clearly underlined. Companies pursue centralization in two regards. Digital platform companies serve as role models for intra-organizational technological adaption processes as well as important channels for content distribution. Criticism regarding surveillance does not emerge. Even among those interviewees who feel committed to the idea of traditional journalism, such as Axel Springer's top-tier manager Ralph Büchi or Belgian Publisher DePersgroep's representative Piet Vroman, concepts as citizen (in contrast to consumer or user) are not mentioned. Yet, the criticism that the interviewed media managers direct toward the digital media platforms is rather that the latter have exclusive access to valuable data, resulting in a competitive advantage for content-based media companies.

Following this, discourse on decentralization is an issue for the interviewees. The widespread demand is that control over user data was distributed more equally across the media market. On a discursive level, technology-related business strategies as presented by the interviewees correspond to critical stands towards centralized digital media platforms. Not throughout the sample, yet quite visibly, interviewees suggest a cooperation of European media in order to build alternative technology infrastructure centers-both in terms of geographies of data collection and distribution. The contentbased media companies' joining in decentralization discourse is particularly interesting because it expands an old debate in a global direction. It was not long ago that they themselves were the objects of criticism. Within national media systems, large content-driven media com- 
panies were regularly criticized for their growth and impact on media markets. Another interesting aspect that sheds light on decentralization processes is the interdependency of both company types as the former deliver content to be used or traded on digital platforms.

Thus, this study shows that it is worth discussing (de)centralization from within a techno-economic perspective by looking at economic agents. It illustrates that, even though content-based media companies suffer from infrastructural disadvantages, they are not likely to be "swallowed" by digital media platforms. The analysis provides two arguments for that. First, we have shown that content-based media companies' links with digital platform interfaces are diverse, some niche market companies tend even to be independent. Especially in the TV business, some refer to the pressure to be visible on global platforms, while still relying on a variety of alternative networks that support their business models. Second, both companies and platforms depend on each other regarding distribution and content. While Facebook, Google or even Amazon, depend, to some extent, on the provision of contribution by media professionals, content-based media companies, can, especially when not relying exclusively on relationships with digital platforms, increase their revenue considerably.

Altogether, content-based media companies are both agents of decentralization discourses and agents of techno-economic regional centralization within the (Western) informational ecosphere. Yet this study could give only preliminary insights into media companies as agents of (de)centralization as the issue emerged in the course of the study (information on the research project provided after peer review). A further promising avenue of investigation might be media company lobbyism in national, transnational, or global political institutions. Not least, the interdependency of technology- and contentbased media companies is a promising field of research as further insights might shift our perspective on legacy media companies.

\section{Acknowledgments}

This article builds on data gathered for a study that was conducted by the research project "Cross-Border Media Communication", funded by the German Research Community (DFG), the Austrian Wissenschaftsfonds (FWF), and the Swiss National Science Foundation (SNF). Additional project information can be found at www.cbmc.info. We owe a special thank you to our research project colleagues for generously allowing us to use their empirical material: Klaus-Dieter Altmeppen, Matthias Karmasin, Pamela Przybylski, and Denise Voci. We are also very grateful for the crucial comments of our colleagues Stephanie Kienzler and Gianna Ehrlich, and the anonymous reviewers for earlier versions. This article was published with the financial support of the Johannes Gutenberg-University of Mainz open-access publishing fund.

\section{Conflict of Interests}

The authors declare no conflict of interests.

\section{References}

Agre, P. E. (2003). P2P and the promise of Internet equality. Communications of the ACM, 46(2), 39-42.

Andreessen, M. (2007). Analyzing the Facebook platform, three weeks in. Blog Pmarca. Retrieved from https:// web.archive.org/web/20071002070223/http://blog. pmarca.com/2007/06/analyzing_the_f.html

Arsenault, A., \& Castells, M. (2008). Switching power. Rupert Murdoch and the global business of media politics. International Sociology, 23(4), 488-513.

Bakker, P. (2008). The simultaneous rise and fall of free and paid newspapers in Europe. Journalism Practice, 2(3), 427-443.

Bernstein, A. A. (1986). Access to cable, natural monopoly, and the first amendment. Columbia Law Review, 86(8), 1663-1696.

Birkinbine, B., Gómez, R., \& Wasko, J. (2017). Global media giants. New York, NY, and London: Routledge.

Coleman, G. (2011). Hacker politics and publics. Public Culture, 23(3), 511-516.

Cooper, D. R., \& Schindler, P. S. (2014). Business research methods (12th ed.). New York, NY: McGraw-Hill Irwin.

Dencik, L., Hintz, A., \& Carey, Z. (2017). Prediction, pre-emption and limits to dissent: Social media and big data uses for policing protests in the United Kingdom. New Media \& Society. doi:10.1177/ 1461444817697722

DiLorenzo, T. J. (1996). The myth of natural monopoly. The Review of Austrian Economics, 9(2), 43-58.

Economides, N. (2008). Net neutrality. Non-discrimination and digital distribution of content through the internet. I/S: A Journal of Law and Policy for the Information Society, 4(2), 209-233.

Fuchs, C. (2017). Facebook. In B. Birkinbine, R. Gómez, \& J. Wasko (Eds.), Global media giants (pp. 428-444). New York, NY, and London: Routledge.

Gillespie, T. (2010). The politics of "platforms". New Media \& Society, 12(3), 347-364.

Gürses, S. (2014). Can you engineer privacy? Communications of the ACM, 57(8), 20-23.

Helmond, A. (2015). The platformization of the web: Making web data platform ready. Social Media \& Society, 1(2), 1-11.

Herbert, J., \& Thurman, N. (2007). Paid content strategies for news websites. An empirical study of British newspapers' online business models. Journalism Practice, $1(2), 208-226$.

Hintz, A. (2014). Outsourcing surveillance-Privatising policy: Communications regulation by commercial intermediaries. Birkbeck Law Review, 2(2), 349-367.

Hofmann, J., Katzenbach, C., \& Gollatz, K. (2014). Between coordination and regulation: Conceptualizing 
governance in Internet governance (HIIG Discussion Paper no. 4). Berlin: HIIG.

Jakubowicz, K. (2013). Bringing public service broadcasting to account. In T. Hujanen \& G. F. Lowe (Eds.), Broadcasting \& convergence: New articulations of the public service remit (pp. 147-165). Göteborg: Nordicom.

Just, N. (2009). Measuring media concentration and diversity: New approaches and instruments in Europe and the USA. Media, Culture \& Society, 31(1), 97-117.

Kubitschko, S. (2015). The role of hackers in countering surveillance and promoting democracy. Media and Communication, 3(2), 77-87.

Kubitschko, S. (2017). Acting on media technologies and infrastructures: Expanding the media as practice approach. Media, Culture \& Society. doi:10.1177/ 0163443717706068

Lyon, D. (2011). Surveillance, power, and everyday life. In P. Kalantzis-Cope \& K. Gherab-Martin (Eds.), Emerging digital spaces in contemporary society. Properties of technology (pp. 107-120). Basingstoke and New York, NY: Palgrave Macmillan.

Mathew, A. J. (2016). The myth of the decentralised Internet. Internet Policy Review, 5(3). doi:10.14763/ 2016.3.425

Matteo, S., \& Dal Zotto, C. (2015). Native advertising, or how to stretch editorial to sponsored content within a transmedia branding era. In G. Siegert, K. Förster, S. M. Chan-Olmsted, \& M. Ots (Eds.), Handbook of media branding (pp. 169-185). Cham: Springer International Publishing.

May, F. C. (2012). Wettbewerb im Presse Grosso? MedienWirtschaft, 9(2), 54-56.

McKelvey, F. (2011). A programmable platform? Drupal, modularity, and the future of the web. Fibreculture 18. Retrieved from http://fibreculturejournal.org/ wp-content/pdfs/FCJ-128Fenwick\%20McKelvey.pdf

Milan, S. (2015). When algorithms shape collective ac- tion: Social media and the dynamics of cloud protesting. Social Media \& Society, 1(2), 1-10.

Milan, S., \& Hintz, A. (2013). Networked collective action and the institutionalized policy debate: Bringing cyberactivism to the policy arena? Policy \& Internet, 5(1), 7-26.

Mullin, B. (2015, January 12). Adweek clarifies article on The Intercept's business model. Poynter. Retrieved from http://www.poynter.org/2015/adweek-clarifies -article-on-the-intercepts-business-model/312001

Nadir. (2012). We need to talk about Facebook. nadir.org. Retrieved from http://www.nadir.org/txt/ We_need_to_talk_about_Facebook.html

Noe, T., \& Parker, G. (2005): Winner take all. Competition, strategy, and the structure of returns in the internet economy. Journal of Economics Management Strategy, 14(1), 141-164.

Patton, M. Q. (2015). Qualitative research and evaluation methods. Integrating theory and practice. Los Angeles, CA: Sage.

Picard, R. G. (2015). Economics of print media. In R. G. Picard \& S. S. Wildman (Eds.), Handbook on the economics of the media (pp. 151-164). Cheltenham: Edward Elgar.

Rieder, B., \& Sire, G. (2014). Conflicts of interest and incentives to bias: A microeconomic critique of Google's tangled position on the Web. New Media \& Society, 16(2), 195-211.

Sasseen, J., Olmstead, K., \& Mitchell, A. (2013). Digital: As mobile grows rapidly, the pressures on news intensify. The state of the news media 2013: An annual report on American journalism. Washington, DC: Pew Research Center's Project for Excellence in Journalism. Retrieved from http://www.stateofthemedia.org/ 2013/digital-as-mobile-grows-rapidly-the-pressureson-news-intensify

Woldt, R. (2002). Konturen des digitalen Kabelmarkts. Sind Vielfalt und offener Zugang gewährleistet? Media Perspektiven, 1, 34-49.

\section{About the Authors}

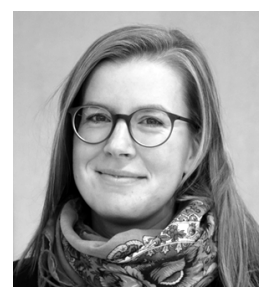

Johanna Möller, Dr., is a postdoc researcher at the Department of Communication, Johannes Gutenberg-University Mainz, Germany, where she works with M. Bjørn von Rimscha on the crossborder communication of media companies. She heads a research project on privacy and encryption in practical politics. Her research interests imply political communication and media sociology, the political dimensions of communication and media technologies at the intersection of political communication and media business as well as cross-border communication.

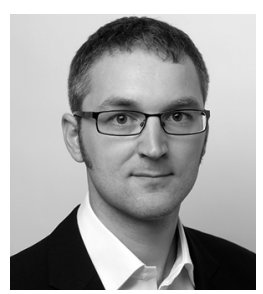

M. Bjørn von Rimscha, Prof. Dr., is professor of media business at Department of Communication, Johannes Gutenberg-University Mainz, Germany, where he heads the study program in media management. Since 2016 he is associate editor of the Journal of Media Business Studies. His research interest is in media management, media economics and cross-border media communication. 
Annex

Table 1. Interview Sample

\begin{tabular}{|c|c|c|c|c|c|c|}
\hline No. & Country & Company & & Media type & Interviewee(s) & Position \\
\hline 1 & AT & ORF-Enterprise & $\begin{array}{l}\text { International content } \\
\text { sales for Austrian TV } \\
\text { market leader ORF }\end{array}$ & $\begin{array}{l}\text { Broadcasting } \\
\text { (audiovisual) }\end{array}$ & $\begin{array}{l}\text { Beatrix Cox- } \\
\text { Riesenfelder }\end{array}$ & CFO \\
\hline 2 & AT & Mediaprint & $\begin{array}{l}\text { One of the biggest } \\
\text { publishers of } \\
\text { newspapers in Austria }\end{array}$ & Publisher (print) & Thomas Kralinger & CEO \\
\hline 3 & AT & $\begin{array}{l}\text { Austria Presse } \\
\text { Agentur (APA) }\end{array}$ & $\begin{array}{l}\text { Leading news agency } \\
\text { in Austria }\end{array}$ & $\begin{array}{l}\text { News } \\
\text { Agency }\end{array}$ & Clemens Pig & CEO \\
\hline 4 & $\mathrm{CH}$ & Diogenes Verlag & $\begin{array}{l}\text { Publisher of fiction } \\
\text { books from German- } \\
\text { language and } \\
\text { international authors }\end{array}$ & $\begin{array}{l}\text { Book Publisher } \\
\text { (print) }\end{array}$ & Stephan Fritsch & $\begin{array}{l}\text { Managing } \\
\text { Director }\end{array}$ \\
\hline 5 & $\mathrm{DE}$ & Axel Springer & $\begin{array}{l}\text { Brands itself as "Europe's } \\
\text { leading digital publisher" } \\
\text { dealing in newspapers } \\
\text { and platforms }\end{array}$ & $\begin{array}{l}\text { Publisher } \\
\text { (print) }\end{array}$ & Ralph Büchi & $\begin{array}{l}\text { President } \\
\text { Inter- } \\
\text { national }\end{array}$ \\
\hline 6 & $\mathrm{DE}$ & $\begin{array}{l}\text { Vogel Business } \\
\text { Media }\end{array}$ & $\begin{array}{l}\text { Publisher of trade } \\
\text { publications }\end{array}$ & $\begin{array}{l}\text { Publisher } \\
\text { (print) }\end{array}$ & $\begin{array}{l}\text { Gunther Schunk } \\
\text { \& Dieter Wendel }\end{array}$ & $\begin{array}{l}\text { CCO } \\
\text { M\&A } \\
\text { Manager }\end{array}$ \\
\hline 7 & $\mathrm{DE}$ & ZDF Enterprises & $\begin{array}{l}\text { International TV- } \\
\text { rights trading and } \\
\text { co-production, most } \\
\text { important customer: } \\
\text { German Public } \\
\text { Service Media }\end{array}$ & $\begin{array}{l}\text { TV content } \\
\text { (audiovisual) }\end{array}$ & $\begin{array}{l}\text { Fred Burcksen \& } \\
\text { Stephan Adrian }\end{array}$ & $\begin{array}{l}\text { Managing } \\
\text { Directors }\end{array}$ \\
\hline 8 & $\mathrm{CH}$ & $\begin{array}{l}\text { Highlight } \\
\text { Communications }\end{array}$ & $\begin{array}{l}\text { Holding with } \\
\text { subsidiaries in film } \\
\text { and sports licensing }\end{array}$ & Rights trader & Bernhard Burgener & President \\
\hline 9 & $\mathrm{CH}$ & Tamedia & $\begin{array}{l}\text { Leading Swiss media } \\
\text { group, publishing and } \\
\text { digital platforms }\end{array}$ & $\begin{array}{l}\text { Publisher } \\
\text { (print \& digital) }\end{array}$ & Marcel Kohler & $\begin{array}{l}\text { Managing } \\
\text { Director }\end{array}$ \\
\hline 10 & $\mathrm{DE}$ & DPA & $\begin{array}{l}\text { Leading German } \\
\text { news agency }\end{array}$ & News Agency & Michael Segbers & CEO \\
\hline 11 & $\mathrm{DE}$ & $\begin{array}{l}\text { Studio Hamburg } \\
\text { Group }\end{array}$ & $\begin{array}{l}\text { One of the German } \\
\text { leading production } \\
\text { and service centers } \\
\text { for film and television }\end{array}$ & $\begin{array}{l}\text { TV content } \\
\text { (audiovisual) }\end{array}$ & Johannes Züll & $\begin{array}{l}\text { Senior } \\
\text { Managing } \\
\text { Director }\end{array}$ \\
\hline 12 & $\mathrm{DE}$ & $\begin{array}{l}\text { Bertelsmann SE } \\
\& \text { Co. KGaA }\end{array}$ & $\begin{array}{l}\text { Diversified media, } \\
\text { services and education } \\
\text { company including, } \\
\text { inter alia, RTL Group } \\
\text { and magazine publisher } \\
\text { Gruner + Jahr }\end{array}$ & $\begin{array}{l}\text { Multimedia } \\
\text { company }\end{array}$ & Shobhna Mohn & $\begin{array}{l}\text { Executive } \\
\text { Vice } \\
\text { President } \\
\text { Growth } \\
\text { Regions }\end{array}$ \\
\hline 13 & $\mathrm{DE}$ & $\begin{array}{l}\text { Motor Presse } \\
\text { Stuttgart GmbH } \\
\& \text { Co. KG }\end{array}$ & $\begin{array}{l}\text { Publisher of special } \\
\text { interest (especially } \\
\text { automotive) }\end{array}$ & $\begin{array}{l}\text { Publisher } \\
\text { (print) }\end{array}$ & $\begin{array}{l}\text { Dr. Volker Breid } \\
\text { CEO }\end{array}$ & \\
\hline
\end{tabular}


Table 1. Interview Sample (cont.)

\begin{tabular}{|c|c|c|c|c|c|c|}
\hline No. & Country & Company & & Media type & Interviewee(s) & Position \\
\hline 14 & UK & $\begin{array}{l}\text { Elsevier } \\
\text { (RELX group) }\end{array}$ & $\begin{array}{l}\text { Publisher of scientific } \\
\text { journals and services }\end{array}$ & $\begin{array}{l}\text { Scientific } \\
\text { publishing }\end{array}$ & Dr. Mark Siebert & $\begin{array}{l}\text { Director } \\
\text { Engagement } \\
\text { Programs, } \\
\text { Strategy }\end{array}$ \\
\hline 15 & UK & $\begin{array}{l}\text { ITV Studios } \\
\text { Limited }\end{array}$ & $\begin{array}{l}\text { UK's biggest TV } \\
\text { production company }\end{array}$ & TV production & Ella Umansky & $\begin{array}{l}\text { Managing } \\
\text { Director }\end{array}$ \\
\hline 16 & European & $\begin{array}{l}\text { European } \\
\text { Broadcasting } \\
\text { Union }\end{array}$ & $\begin{array}{l}\text { Alliance of PSM in } \\
\text { Europe and beyond } \\
\text { providing technical } \\
\text { services and sports } \\
\text { licenses }\end{array}$ & $\begin{array}{l}\text { Broadcasting } \\
\text { (audiovisual) }\end{array}$ & Ingrid Deltenre & $\begin{array}{l}\text { General } \\
\text { Secretary }\end{array}$ \\
\hline 17 & USA & $\begin{array}{l}\text { Thomson } \\
\text { Reuters }\end{array}$ & $\begin{array}{l}\text { Provides expert } \\
\text { information in finance, } \\
\text { economics and law, } \\
\text { owns the Reuters } \\
\text { news agency }\end{array}$ & $\begin{array}{l}\text { Information } \\
\text { broker }\end{array}$ & $\begin{array}{l}\text { Gonzalo } \\
\text { Lissarague }\end{array}$ & $\begin{array}{l}\text { President } \\
\text { Global } \\
\text { Growth } \\
\text { Organization }\end{array}$ \\
\hline 18 & USA & $\begin{array}{l}\text { Story House } \\
\text { Media Group }\end{array}$ & $\begin{array}{l}\text { Produces primarily non- } \\
\text { fictional TV content in } \\
\text { the US and Germany }\end{array}$ & $\begin{array}{l}\text { TV production } \\
\text { company } \\
\text { (audiovisual) }\end{array}$ & Andreas Gutzeit & $\begin{array}{l}\text { Chief } \\
\text { Creative } \\
\text { Officer }\end{array}$ \\
\hline 19 & USA & $\begin{array}{l}\text { Time Warner } \\
\text { Inc. }\end{array}$ & $\begin{array}{l}\text { Company focusing on } \\
\text { TV, TV networks, film } \\
\text { and TV entertainment }\end{array}$ & $\begin{array}{l}\text { TV and Film } \\
\text { content } \\
\text { (audiovisual) }\end{array}$ & Manuel Urrutia & $\begin{array}{l}\text { Senior Vice } \\
\text { President, } \\
\text { International } \\
\text { and Corporate } \\
\text { Strategy }\end{array}$ \\
\hline 20 & USA & $\begin{array}{l}\text { Tribune Content } \\
\text { Agency (TCA; } \\
\text { Teil von tronc) }\end{array}$ & $\begin{array}{l}\text { Distributes the print } \\
\text { content provided by } \\
\text { tronc newspapers } \\
\text { and others }\end{array}$ & News agency & Wayne Lown & $\begin{array}{l}\text { International } \\
\text { Sales } \\
\text { Director }\end{array}$ \\
\hline 21 & USA & Time Inc. & $\begin{array}{l}\text { Multi-platform media } \\
\text { company coming } \\
\text { sourcing from its } \\
\text { magazine brands }\end{array}$ & $\begin{array}{l}\text { From Publisher } \\
\text { to multi-platform } \\
\text { company }\end{array}$ & Steve Marcopoto & $\begin{array}{l}\text { President, } \\
\text { Time Inc. } \\
\text { International }\end{array}$ \\
\hline 22 & USA & $\begin{array}{l}\text { Discovery } \\
\text { Networks } \\
\text { International }\end{array}$ & $\begin{array}{l}\text { Distributing cable } \\
\text { networks as wells as } \\
\text { pay and free TV } \\
\text { channels worldwide } \\
\text { and providing TV } \\
\text { content }\end{array}$ & $\begin{array}{l}\text { TV networks } \\
\text { and TV } \\
\text { content }\end{array}$ & Jennifer Marburg & $\begin{array}{l}\text { Vice President } \\
\text { of Consumer } \\
\text { Program } \\
\text { Publicity }\end{array}$ \\
\hline 23 & $\mathrm{BE}$ & DePersgroep & $\begin{array}{l}\text { Multimedia company, } \\
\text { focus on newspapers } \\
\text { and magazines }\end{array}$ & $\begin{array}{l}\text { Newspaper, } \\
\text { magazines, } \\
\text { TV, Radio, Digital }\end{array}$ & Piet Vroman & CFO \\
\hline 24 & $\mathrm{DE}$ & $\begin{array}{l}\text { Hubert Burda } \\
\text { Media }\end{array}$ & $\begin{array}{l}\text { International multi- } \\
\text { media company }\end{array}$ & $\begin{array}{l}\text { Magazines, } \\
\text { platforms, events }\end{array}$ & Eckart Bollmann & $\begin{array}{l}\text { CEO Burda } \\
\text { International }\end{array}$ \\
\hline 25 & UK & Time Inc. UK & $\begin{array}{l}\text { Content-Trader, } \\
\text { Multi-Platform Media } \\
\text { and Related Business } \\
\text { Corporation }\end{array}$ & $\begin{array}{l}\text { From } \\
\text { publisher to } \\
\text { Multi-Platform }\end{array}$ & Marcus Rich & CEO \\
\hline 26 & ES & Grupo Secuoya & $\begin{array}{l}\text { Largest independent } \\
\text { audiovisual group in } \\
\text { the Spanish media } \\
\text { market }\end{array}$ & $\begin{array}{l}\text { TV Content } \\
\text { (Audiovisual) }\end{array}$ & $\begin{array}{l}\text { José Miguel } \\
\text { Barrera }\end{array}$ & $\begin{array}{l}\text { Head of } \\
\text { international }\end{array}$ \\
\hline
\end{tabular}

